Zhernovnykova Oksana, Kovalenko Oksana, Mkrtichian Oksana, Zelenska Liudmyla. Evaluation of the professional teaching competence: chinese experience. Journal of Education, Health and Sport. 2020;10(3):199-207. eISSN 2391-8306. DOI http://dx.doi.org/10.12775/JEHS.2020.10.03.022

https://apcz.umk.pl/czasopisma/index.php/JEHS/article/view/JEHS.2020.10.03.022

https://zenodo.org/record/3757294

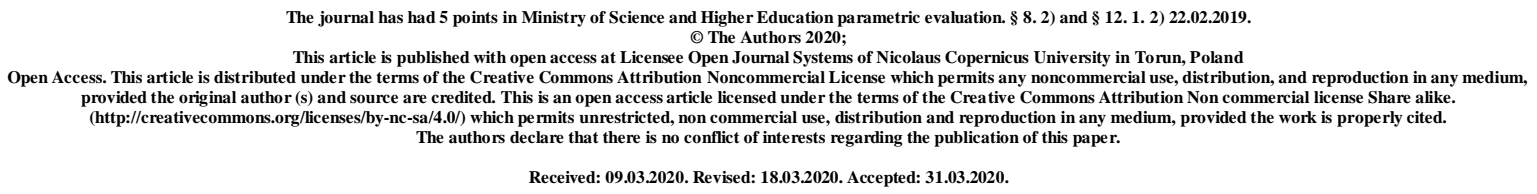

UDC 378.147:372

\title{
EVALUATION OF THE PROFESSIONAL TEACHING COMPETENCE: CHINESE EXPERIENCE
}

\author{
Oksana Zhernovnykova \\ oazhernovnykova@gmail.com \\ Oksana Kovalenko \\ 04.08.1975@hnpu.edu.ua \\ Oksana Mkrtichian \\ mkrtichan79@gmail.com \\ Liudmyla Zelenska \\ zelenskaya_ludmila@ukr.net
}

\section{H. S. Skovoroda Kharkiv National Pedagogical University, Ukraine}

\begin{abstract}
The article describes the rules and procedures for hiring and evaluating the professional competence of teachers on the example of China, where there is a system for evaluating the professional competence of teachers.

Keywords: teachers' professional competence; Chinese evaluation experience; quality of general education; tests on pedagogy and teaching methods.

\section{Relevance of the research}

In numerous studies devoted to the search and analysis of the main factors affecting the quality of general education, it is convincingly proved that such a factor is the qualification of a teacher. Therefore, it is not a coincidence that recently foreign and domestic researchers have been making attempts to formally determine the quality of teacher training.
\end{abstract}


The results of such studies are of undoubted interest for researchers of various problems of modernization of higher professional pedagogical education and can be used both in developing the content of the future teacher's professional training, in choosing educational technologies adequate to modern requirements, in the methods of final certification, and in determining various forms of interaction between the school and the university $[1 ; 2 ; 3]$. Of course, the results of such studies are of interest to educational establishments for advanced training and retraining of teachers.

\section{Analysis of previous research}

Teacher has always been and remains a key figure in any society, so it's a problem Improving teacher training is always relevant. Today this is especially acute many Asian countries are facing this problem. These countries include China, whose experience is active studied by renowned scholars, practitioners and educational organizers, including: Zhu Xudong, Editor-in-Chief Hu Yan (Chinese Education Reform 30 Year) [4]; Zhu Xiaoman, Balevs Kaya, Editor-in-Chief Pauli Kokov (Comparison of Sino-Russian Educational Reforms at the Turn of the 20th and 21st Century) [5]; Li Jing (development and experience of continuing education for primary and middle school teachers in China) [6]; Liu Difang (Review and Prospect of School-based Training for Ten Years) [7]; Ding Xiaodong (Three on school-based training Thinking) [8]; Peng Yaqing (Exploration of web-based teacher training strategies) [9].

\section{Presenting main material}

It is for these reasons that today at various levels different countries' national strategies of modernizing teacher training systems, evaluating their qualification at hiring and promoting are actively discussed.

It should be noted that assessing the professional competence of a teacher at different stages of his/her professional career is one of the most important areas of state educational policy, therefore, in many countries there is a fairly stable system for selecting teachers and assessing their readiness for pedagogical activity.

\section{Selection of applicants}

We will describe the rules and procedures for hiring and evaluating the professional competence of teachers on the example of China [1], where a system for assessing the professional competence of teachers has been developed.

In China, for rather long time, teachers have been hired on the basis of exam results. Examinations for teachers applying for work in local comprehensive schools are conducted by prefectural leaders, and teachers are assigned to schools only on the basis of the results of these exams. The procedure and content of examinations are different in different 
departments, but, as a rule, an exam consists of a test in two specialized subjects, namely a pedagogical test (theory and teaching methodology) and a test in a basic subject, as well as interviews and practical tasks. In recent years, in addition to the traditional procedure, several departments of education have diversified the content of examination tests and introduced new criteria and new selection procedures focused on taking into account personal qualities of applicants and their experience.

Below is an example of tests and a procedure for selecting applicants for local schools in Hangzhou Prefecture, where testing is carried out in two stages. The first test is conducted in the month of July (before the school year), the second test is carried out in September for those who have successfully passed the first test. In Hangzhou Prefecture, exams for jobseekers for a teacher's job are developed separately for elementary school, primary school (middle level), senior high school level, as well as for a teacher-educator. Table 1 presents the testing areas for the first test, as well as the testing methods used in the first and second stages of testing.

Table 1

\begin{tabular}{|c|c|c|}
\hline Sphere of activity & $\begin{array}{l}\text { Test } 1 \\
\end{array}$ & Test 2 \\
\hline $\begin{array}{c}\text { Primary school } \\
\text { teacher }\end{array}$ & $\begin{array}{c}\text { - pedagogy and teaching methods } \\
\text { - specialized subjects (for elementary } \\
\text { school - all subjects) } \\
\text { - test interview (group) }\end{array}$ & $\begin{array}{l}\text { - test-interview (individual) } \\
\text { - suitability test } \\
\text { - micro teaching } \\
\text { - practical exercises in the gym } \\
\text { - practical tasks on the PC }\end{array}$ \\
\hline $\begin{array}{l}\text { Middle school } \\
\text { teacher }\end{array}$ & $\begin{array}{l}\text { - pedagogy and teaching methods } \\
\text { - specialized subjects } \\
\text { - test interview (group) } \\
\text { - practical tasks (only for applicants } \\
\text { for a place as a teacher of physical } \\
\text { education, music, art and English) }\end{array}$ & $\begin{array}{l}\text { - test interview (individual) } \\
\text { - suitability test } \\
\text { - micro teaching } \\
\text { - practical tasks (only for } \\
\text { applicants for the place of } \\
\text { teacher of economics) } \\
\text { - practical tasks on the PC }\end{array}$ \\
\hline $\begin{array}{l}\text { High school } \\
\text { teacher }\end{array}$ & $\begin{array}{l}\text { - pedagogy and teaching methods } \\
\text { - specialized subjects } \\
\text { - test interview (group) } \\
\text { - practical tasks (only for applicants } \\
\text { for a place as a teacher of physical } \\
\text { education, music, art and English) }\end{array}$ & $\begin{array}{l}\text { - test interview (individual) } \\
\text { - suitability test } \\
\text { - micro teaching } \\
\text { - practical tasks (only for } \\
\text { applicants for the place of } \\
\text { teacher of housekeeping) } \\
\text { - practical tasks on the PC }\end{array}$ \\
\hline School nurse & $\begin{array}{c}\text { - pedagogy and teaching methods } \\
\text { - specialized subjects } \\
\text { - test - interview (group) }\end{array}$ & $\begin{array}{l}\text { - test interviews (group and } \\
\text { individual) } \\
\text { - suitability test } \\
\text { - practical tasks on the PC }\end{array}$ \\
\hline
\end{tabular}

We characterize the content of the tests and the procedures for their implementation in more detail. 
Test 1. Pedagogy and teaching methods. The first test in pedagogy and teaching methodology is passed by all applicants. The content of the test is focused on testing knowledge in the field of modern theories and concepts of teaching.

Specialized subjects. Teachers applying for a place in primary school take a test in all subjects of the primary school curriculum. Teachers who want to work in primary and secondary school pass the test in the subject they are going to teach.

Test interview. Test interviews are also submitted by all applicants. In a group interview, seven or eight applicants are simultaneously interviewed. The content of the test concerns the understanding of the urgent problems of education in the country as a whole and in Hangzhou, in particular.

Practical exercises. In the first test, practical tasks are given only to applicants for a place as a teacher of physical education, music, art and English in a primary and secondary school. Applicants for the place of a teacher of physical education, music, art perform practical tasks in their subject, and applicants for the place of a teacher of English speak English.

Test 2. Test interview. Testing of the second stage begins with a test interview, to which all applicants who have passed the first test are allowed. Interviews are carried out individually. The questionnaire contains special questions about the applicant's abilities and previous learning experience.

Suitability test. Psychological tests, such as an IQ test, may be offered to applicants.

Micro teaching. The second test must be passed by all applicants for the school teacher's place (this task is not offered to educators. Within 15 minutes, the applicant draws up a plan of a fragment of the lesson on the proposed topic in the presence of the examiner; then he must implement his plan within 8 minutes. After micro-teaching, a short interview.

Practical tasks on the PC. Practical tasks on the computer are offered to all applicants. The content of the test includes tasks such as creating a document in Word, spreadsheets in Excel, Internet skills, etc.

These tests must be taken by all applicants for the position of teacher or educator in school. Applicants who successfully pass the tests are exempt from further exams in the fall. Applicants who successfully pass the test are interviewed before being hired for a job, on the basis of the interview the school where the applicant will go to work is determined.

Applicants who successfully pass the test are hired with a trial period of one year. During this period, new teachers undergo introductory instructional trainings and are 
officially appointed to the position only if they develop positively during this probationary period.

Recently, there has been a tendency to move away from conducting examinations for employment in the form of tests (on a paper basis). Increasing emphasis is being placed on interviews and practical exercises. As mentioned above, many local departments of public education include methods of working on the PC as a necessary component of the skills of a school teacher in the information society in the content of tests.

Universities play a special role in preparing a teacher for the exam. For example, at the University of Hangzhou the such system of work as a teacher's adaptation system has been developed. The system includes the following components:

A meeting-lecture to prepare for the exam for job seekers takes place on the following topics: "Portrait of a Teacher Required in Hangzhou Prefecture" or "Preparing for an Interview".

A meeting at which clarification of the contents and exam procedures for job seekers takes place.

A short lecture on the teaching profession on the topic: "What the exam for job seekers, for students who would like to be implemented in the teaching professionshould be".

Preparatory work for the exam.

Support for a student who hopes to be accepted as a teacher (part-time trial) for his work in the next school year.

Exam for job seekers - preparation of documents.

Examination for applicants - a meeting for successful candidates.

Meeting-lecture, to which students-candidates for teacher positions, who successfully passed the test at the workplace, are invited. This lecture discusses the current problems of teaching methods for selected subjects, conducts individual and group interviews, as well as aptitude test.

Organization of a visit to the Ministry of Education and local education authorities.

All schools have their own recruitment systems, however, through registration and funding mechanisms, they are linked to the basic national standard for teacher qualifications.

2. Certification. The teacher must obtain a modern teacher's certificate, which is developed on the basis of the Law on personal educational certificates and issued by the prefectural departments of education.

For each type of school, there are three categories of certificates: regular, special and temporary. The first two are for teachers, and the last is for teacher assistants. Certificates for 
primary school teachers (middle and high school) are classified by subject. Therefore, teachers of middle and senior classes teach the subject in which they received a certificate, while the certificate of teachers of preschool education and primary school gives the right to teach all subjects.

There are three types of basic teacher certificates: advanced, first and second class. Teachers who have advanced certificates are awarded a master's degree. Those with a first class certificate receive a bachelor's degree. A second-class certificate means a teacher's assistant qualification equivalent to that obtained at the end of college. For example, a student who wants to receive a first-class certificate of an elementary school teacher must have 8 credits for studying pedagogy and teaching methods, 41 credits for specialty discipline and 10 credits for a course taken at a university or other educational institution on pedagogy, methodology or discipline of specialization, approved by the Minister.

In addition, the student must receive 41 credits for teaching practice, teaching specialization disciplines, including preparation for teaching practice and lectures delivered at university courses.

Table 2 shows the correspondence of the type of certificate to the number of credits received in the required disciplines.

Table 2

\begin{tabular}{|c|c|c|c|c|c|}
\hline School type & $\begin{array}{l}\text { Teacher's } \\
\text { certificate } \\
\text { type }\end{array}$ & $\begin{array}{l}\text { Pedagogy, } \\
\text { teaching } \\
\text { methodology }\end{array}$ & $\begin{array}{c}\text { Specialty } \\
\text { disciplines }\end{array}$ & $\begin{array}{l}\text { Pedagogy, } \\
\text { teaching } \\
\text { methodology } \\
\text { / specialty } \\
\text { disciplines }\end{array}$ & $\begin{array}{l}\text { Specialty } \\
\text { disciplines } \\
\text { (for the } \\
\text { system of } \\
\text { specialized } \\
\text { education) }\end{array}$ \\
\hline \multirow[t]{3}{*}{ Primary school } & Advanced & 8 & 41 & 34 & \\
\hline & First class & 8 & 41 & 10 & \\
\hline & Second class & 4 & 31 & 2 & \\
\hline \multirow[t]{3}{*}{ Secondary school } & Advanced & 20 & 31 & 32 & \\
\hline & First class & 20 & 31 & 8 & \\
\hline & Second class & 10 & 21 & 4 & \\
\hline \multirow[t]{2}{*}{ Middle school } & Advanced & 20 & 23 & 40 & \\
\hline & First class & 20 & 23 & 16 & \\
\hline \multirow{3}{*}{$\begin{array}{l}\text { Schools for the } \\
\text { blind, deaf and } \\
\text { children with } \\
\text { developmental } \\
\text { problems }\end{array}$} & Advanced & & & & 47 \\
\hline & First class & & & & 23 \\
\hline & Second class & & & & 13 \\
\hline \multirow{3}{*}{$\begin{array}{l}\text { Preschool } \\
\text { education }\end{array}$} & Advanced & 6 & 35 & 34 & \\
\hline & First class & 6 & 35 & 10 & \\
\hline & Second class & 4 & 27 & & \\
\hline
\end{tabular}


3. The image of the teacher. In China, as in many other countries, much attention is paid to the value component of teacher training and certification. We will briefly describe the image of the Teacher that has developed in the educational community of China.

A teacher is an excellent member of society.

The teacher has the ability to social and human communication:

A. Teacher - an accomplished adult of a broad culture whose actions are consistent and reliable;

B. The teacher adequately evaluates relationships between people and flexibly plans human relationships.

The teacher is a mobile and sociable person:

A. The teacher is able to consider different points of view and opinions and respects different value scales;

B. A teacher works with staff, parents, and colleagues and can build a better school and a better society.

The teacher is capable of self-organization and self-development:

A. The teacher has high ethical views and can control himself;

B. The teacher has exemplary self-awareness and successfully fulfills his duties.

The teacher deeply understands his subject:

A. The teacher has excellent knowledge and skills in the subject;

B. The teacher organizes learning activities based on the student's understanding;

C. The teacher takes into account the feelings of the student and can give instructions appropriate to the situation.

The teacher has managerial abilities:

A. The teacher is able to manage the class, capturing the feelings of students and effectively using the achievements of students;

B. The teacher is confidently involved in school management as a member of the school organization;

C. The teacher draws up a curriculum that matches the actual learning environment of students.

The teacher has adaptive abilities, responds to changes in society:

A. The teacher is constantly upgrading skills and is always ready for self-education;

B. The teacher freely and creatively works with the new curriculum that accompanies changes in the society. 
The teacher carries out professional activities with deep love for the student and the awareness of the importance of his/her mission:

A. The teacher understands the student's growth and development, respects the student's difficulties and feelings, and can support the student's point of view;

B. The teacher respects human rights and can share joy with the student;

C. The teacher observes the student's virtues and promotes their development.

The teacher has communicative abilities:

A. The teacher makes logical judgments, understanding the position of the partner;

B. The teacher recognizes the meaning of the statement of the partner and conducts dialogue adequately to the feelings of the partner.

\section{Conclusions}

Therefore, we conclude that the foreign experience of evaluating the professional competence of a teacher is interesting not only for the formation of a general idea of such actions carried out for hiring teachers. On this basis, practical recommendations on the certification procedure for teachers can be developed, which are based not only on the analysis of domestic experience in certification of teaching staff, modern concepts of evaluating the quality of education abroad, but also on the use of modern international experience in assessing the professional competence of teachers. Obviously, today in modern sociocultural conditions, there is a need for certification of teachers in accordance with the following criteria: the ability to design and implement an effective and meaningful process of learning and teaching, including the use of teaching and assessment technologies, to create a promising educational environment that encourages students to unlock their potential; the ability to apply relevant knowledge to design an individual educational route for a student, i.e. to plan and prepare teaching and learning programs, taking into account different needs and learning styles of students; as well as relevant curriculum, study programs and educational trends; the ability to effectively interact with students, including the use of appropriate communication skills, as well as to plan and apply appropriate strategies for establishing and maintaining a supportive educational environment; understanding of the need to work with other school teachers and representatives of the local community to establish productive partnerships and achieve educational goals.

\section{References:}

1. 教育部 于加 中小学在 教 培 工作的意.中 人民共 和国重要教育文献 (1976-1990). 海口:海南出版社,1998. 2058. [Opinions of the Ministry of Education on Strengthening the 
Training of In-service Teachers in Primary and Secondary Schools. Important Educational Documents of the People's Republic of China (1976-1990). Haikou: Hainan Publishing House, 1998. 2058 p.]

2. 中 人民共和国教育大事 (1949-1982). 北京: 教育科学出版社, 1984.700 . [Chronicle of Education in the People's Republic of China (1949-1982). - Beijing: Educational Science Press, 1984. 700 p.].

3. 我国教育学院的非常大 展及 策 高等教 教育研究 1987. № 1. 5. [The great development and countermeasures of our country 's educational institutes. Research on Higher Teacher Education. 1987. № 1. P. 5].

4. 中国教育改革30年: 教 教育卷朱旭, 胡 主. 北京: 北京 范大学出版社, 2009. 250. [Chinese Education Reform 30 Year: Teacher Education Volume / Zhu Xudong, Editor-inChief Hu Yan. Beijing: Beijing Normal University Press, 2009. 250 p.].

5. 20-21世 之交中俄教育改革比/朱小䒤，（俄 斯）列㚘斯卡（俄斯）利幸柯夫主 北京: 教育科学出版社, 2006. 508. [Comparison of Sino-Russian Educational Reforms at the Turn of the 20th and 21st Century / Zhu Xiaoman, (Russia) Balevs Kaya, (Russia) Editor-in-Chief Pauli Kokov. Beijing: Educational Science Press, 2006. 508 p.].

6. 李晶. 我国中小学教 教育展及所取得的 北京教育学院学. 2008. 第22卷第3期. 2325. [Li Jing. The development and experience of continuing education for primary and middle school teachers in China. Journal of Beijing Institute of Education. 2008. Vol. 22, Is. 3. P. 23$25]$.

7. 刘堤仿.校本培 十年回眸与展望 中小学教 培 2008. № 10. 18-20. [Liu Difang. Review and Prospect of School-based Training for Ten Years. Teacher Training for Primary and Secondary Schools. 2008. № 10. P. 18-20].

8. 丁 校本培 的三点思考. 曲靖 范学院学. 2009. 第28卷第6期. 77-80. [Ding Xiaodong. Three on school-based training Thinking. Journal of Qujing Teachers College. 2009. Vol. 28. №6. P. 77-80].

9. 彭 青.基于网 的教培策略的探索 中小学教 培 2007. № 4. 18-19. [Peng Yaqing. Exploration of web-based teacher training strategies. Primary and secondary school teacher training. 2007. № 4 . P. 18-19]. 